\title{
NATURAL AND MAN-INDUCED HAZARDS ALONG THE DANUBE, BETWEEN RAST AND GIGHERA SETTLEMENTS, WITH A SPECIAL VIEW ON THE 2006 FLOOD
}

\author{
Mihaela Licurici, Sandu Boengiu, OAna Ionuş \\ University of Craiova, Geography Department, Craiova, Dolj County, Romania
}

Manuscript received: September 20, 2010

Revised version: December 12, 2010

Licurici M., Boengiu S., Ionuş O., 2011. Natural and man-induced hazards along the Danube, between Rast and Gighera settlements, with a special view on the 2006 flood. Quaestiones Geographicae 30(1), Bogucki Wydawnictwo Naukowe, Poznań, pp. 57-68, 13 Figs., 4 Tabs. ISBN 978-83-62662-39-5. ISSN 0137-477X. DOI 10.2478/ v10117-011-0005-1.

\begin{abstract}
АвSTRACT. The paper discusses the natural and man-induced hazards in the Rast-Gighera sector of the Danube Floodplain, an area displaying asymmetric character, with the high and steep slopes of the Prebalcanic Tableland dominating the low Romanian floodplain. The subject regards an acute present problem, the necessity to improve the management of dangerous phenomena included among the objectives for this millennium. Moreover, the paper regards a space with an exceptional natural heritage that has been seriously transformed by man, the natural-human opposition becoming the key-element of the region. The complexity of the subject is given by the plurality of causes that lead to the genesis of hazards. Their nature, frequency and intensity, along with other factors of psychological or economic nature imply different answers from the part of the affected population.
\end{abstract}

In the past, the region was characterised by the significant presence of swampy areas, lakes and ponds connected to the Danube through secondary branches, being under the influence of the level oscillations of the river. The relief was strongly modified, especially during the last hundred years, the human factor exerting an important influence, mainly through flood-control dykes and dams, networks of irrigation and drainage channels, deforestation, so that extended surfaces that had been naturally covered by waters and forests were converted to agriculture.

KEYWORDs: Danube Floodplain, flood, regulation works, land degradation, natural hazard, reconstruction

Mihaela Licurici, University of Craiova, Geography Department, Al. I. Cuza Street, No. 13, Craiova, Dolj County, Romania, e-mail: mihaela_licurici@yahoo.com

\section{Introduction}

\section{Natural Resources}

\section{Relief}

The area under study is located between Rast settlement in the west and Gighera settlement in the east, entirely on the Danube Floodplain, on a sector having asymmetric character, with the high and steep slopes of the Prebalcanic Tableland, dominating the low Romanian floodplain of the river.

The southern limit is clear, while the northern one has a sinuous aspect, marked by the chain of settlements situated at the floodplain - terrace contact or on the surface of the neighbouring terrace, i.e.: Rast, Negoi, Catane, Bistreț, Cârna, Măceşu de Jos, and Gighera. 
The floodplain shows a diversity of microrelief features and is generally characterised by the presence of longitudinal zones: the sandbank located near the riverbed (the highest part), the middle alluvial plain (partially swampy) and the depressions (swamps and lakes, most of them drained in the past). There is a $54 \mathrm{~km}$ long sector, featuring the same morphometric characteristics; it is more extended eastward (maximum width: $11 \mathrm{~km}$, south of Cârna settlement) than westward (minimum width: $3 \mathrm{~km}$ south of Rast settlement, Fig. 1). This extension is entirely due to the lateral action of the Danube, to the separation that took place in the riverbed and to the general Holocene tendency to shift towards the right. The entire area constructed by the Danube through alluviation and subject to the direct action of the Danube water bears the name of Danube Floodplain (***, 1969). Significant changes appear locally, generated by enhanced alluviation and by the presence of sand dunes and of alluvial fans.

After the infilling of the left river branch, there resulted lakes, ponds, streams and marshes on this space, while the islet located between the branches was shaped by the wind. The highest elevations occur along the present course of the Danube (natural levees); the transition floodplain is locally covered with sand dunes, while at the contact with the terraces backswamps developed.

In natural regime, within this sector of the floodplain frequent floods took place, the Danube supplying the ponds with waters and clogging them at the same time. The inundation was done both directly and indirectly by the Danube.

\section{Climatic features}

The region has a predominantly temperatecontinental climate, with sub-Mediterranean influences and expressed aridity. The analysed parameters were registered at two meteorological stations (Bechet and Calafat) located to the east, respectively west of the study area. Solar radiation and heat availability parameters are higher than the values registered in the rest of the country (except for the seaside area), the mean multiannual temperature is high and presents little variations $\left(11.4^{\circ} \mathrm{C}\right.$ at Bechet station, $11.8^{\circ} \mathrm{C}$ at Calafat station). Mean monthly maximum temperatures show positive values all through the year, while the mean monthly minimum temperature displays negative values for three months of the year (December to February) (Vlădut 2007).

The mean multi-annual precipitation quantity lowers gradually from the west to the east (Calafat - ca $518.0 \mathrm{~mm}$, while at Bechet - 508.3

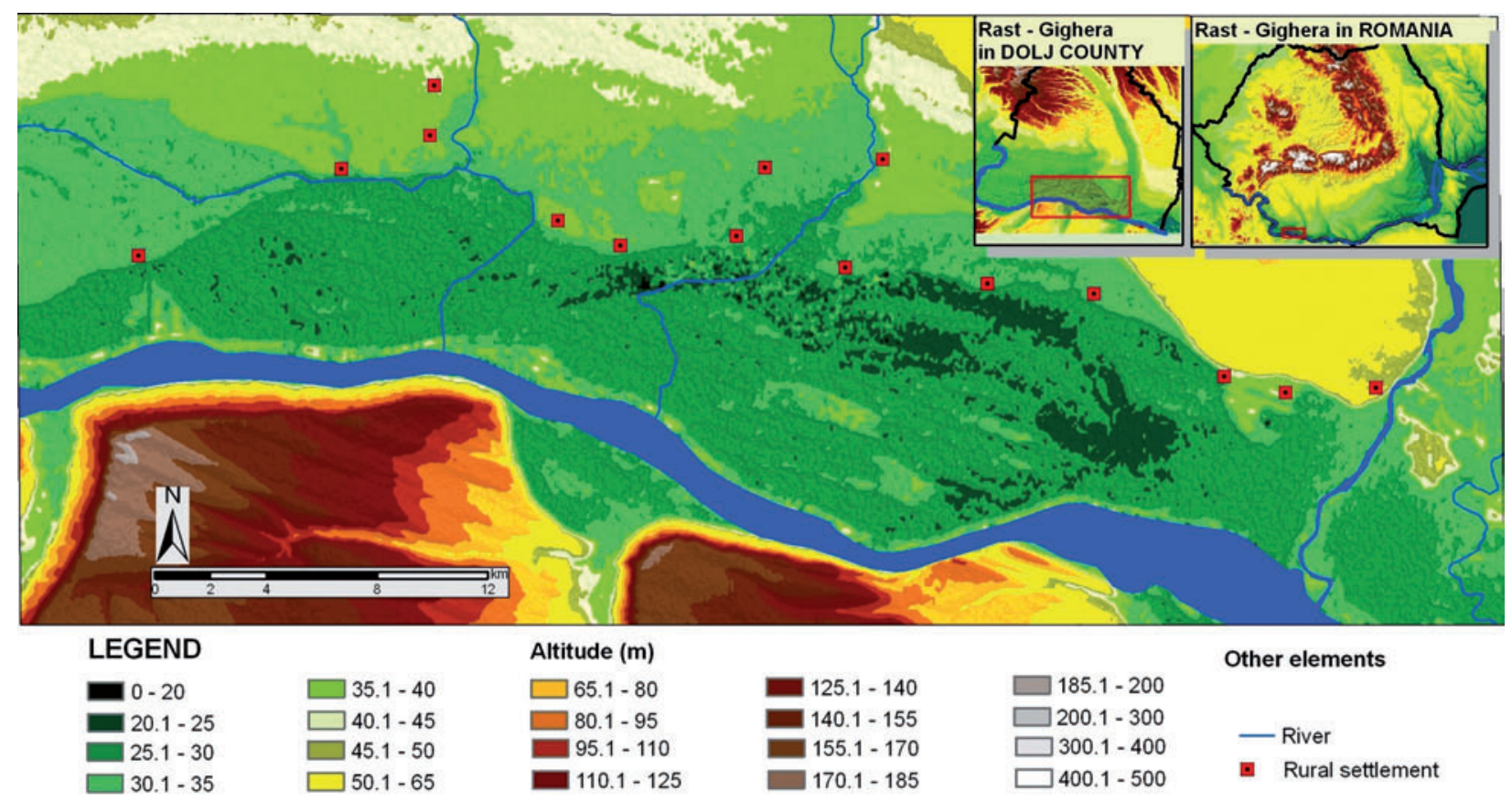

Fig. 1. The Rast - Gighera sector of the Danube Floodplain. Hypsometry 
$\mathrm{mm})$. The interval with the heaviest rains is May-June (the mean multi - annual value of June being of $62.6 \mathrm{~mm}$ at Bechet and $55.8 \mathrm{~mm}$ at Calafat), a second pluvial maximum being registered in November (47.2 $\mathrm{mm}$ at Bechet and 48.6 $\mathrm{mm}$ at Calafat). The absolute maximum precipitation quantities within 24 hours are most important (sometimes exceptional) in the western part, where the influence of the Mediterranean cyclones and of the thermal convection on the sand is higher. The highest monthly precipitation was registered in June 1940, at Calafat $497.0 \mathrm{~mm}$.

The correlation of the thermal values from past years with the corresponding precipitation amounts and with the social-economic background of the region reveals a problematic situation and underlines the need for appropriate management. The region is affected by more and more severe droughts and the frequency of torrential rains with catastrophic effects also increased. In 2000, 2001, 2007 the crops were partially or totally destroyed.

The solution could be represented by the reforestation of the areas where the sands became mobile, along with the restoration of the irrigation system, which could supplement the lack or the deficit of precipitation (Vlăduț 2007).

\section{Hydrography}

The Danube represents the central hydrographical axis of the region, to which there are to be added the tributaries received from the North (among the most important being the Balasan, the Desnățui and the Jiu Rivers).

The slope changes, induced by the passage of the river from the mountain to the plain area and by the neotectonic movements that are different in direction and intensity, triggered significant alluviation. Thus, river depths are reduced, current velocity drops, the river channel shows an anastomosing pattern with islands of gravels and sands. The slope of the riverbed has values of $0.8-0.4 \%$, while the current velocity is ca $1.8-0.5$ $\mathrm{m} \mathrm{s}^{-1}$.

Due to the low altitudes, in the past the region was characterised by the presence of swamps, lakes and ponds connected to the Danube through secondary branches and were under the influence of level oscillations of the Danube (Fig. 2).

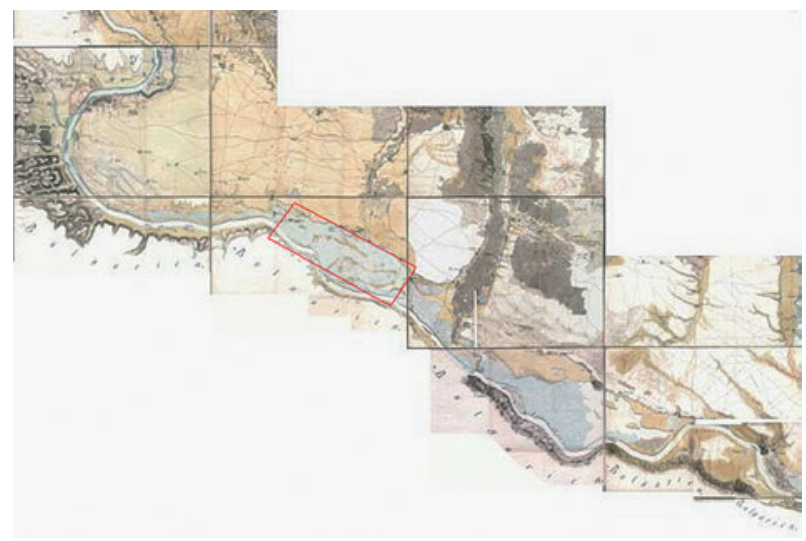

Fig. 2. Sample of the Specht Map (1790) including the Dolj sector of the Danube Floodplain (after Dumitraşcu, 2006)

\section{Human resources}

\section{Demographic and administrative aspects. Infrastructure}

At present, eight territorial-administrative units include part of their territory in the Danube Floodplain: Rast, Negoi, Catane, Bistreț, Goicea, Carna, Măceşu de Jos, Gighera (Fig. 3).

The total number of inhabited villages that belong to the above mentioned settlements is 15, including a population of 21,594 persons (Dolj Regional Statistics Direction 2008). The accentuated aging phenomenon and the negative natural growth represent the essential demographic features of the region. Under these circumstances, the general density of the population is much under the national value, often even under the limit of 40 people $\mathrm{km}^{-2}$ (Gighera - 27.6 people $\mathrm{km}^{-2}$ ).

\section{Data and methods}

In order to have a better view on the present significance of the natural and man-induced hazards, it was first necessary to analyze the dynamics of the natural support under the human intervention influence. The analysis of the relief has been conducted based on the topographical maps at scales of 1:25,000, 1:50,000, 1:100,000, forest distribution maps, hydrogeological maps, SRTM DTM at 30 meters and Corine Land Cover data in GIS environment.

The processing of different generations of maps and orthophotographs that are characteristic for the past two centuries permitted the assessments 


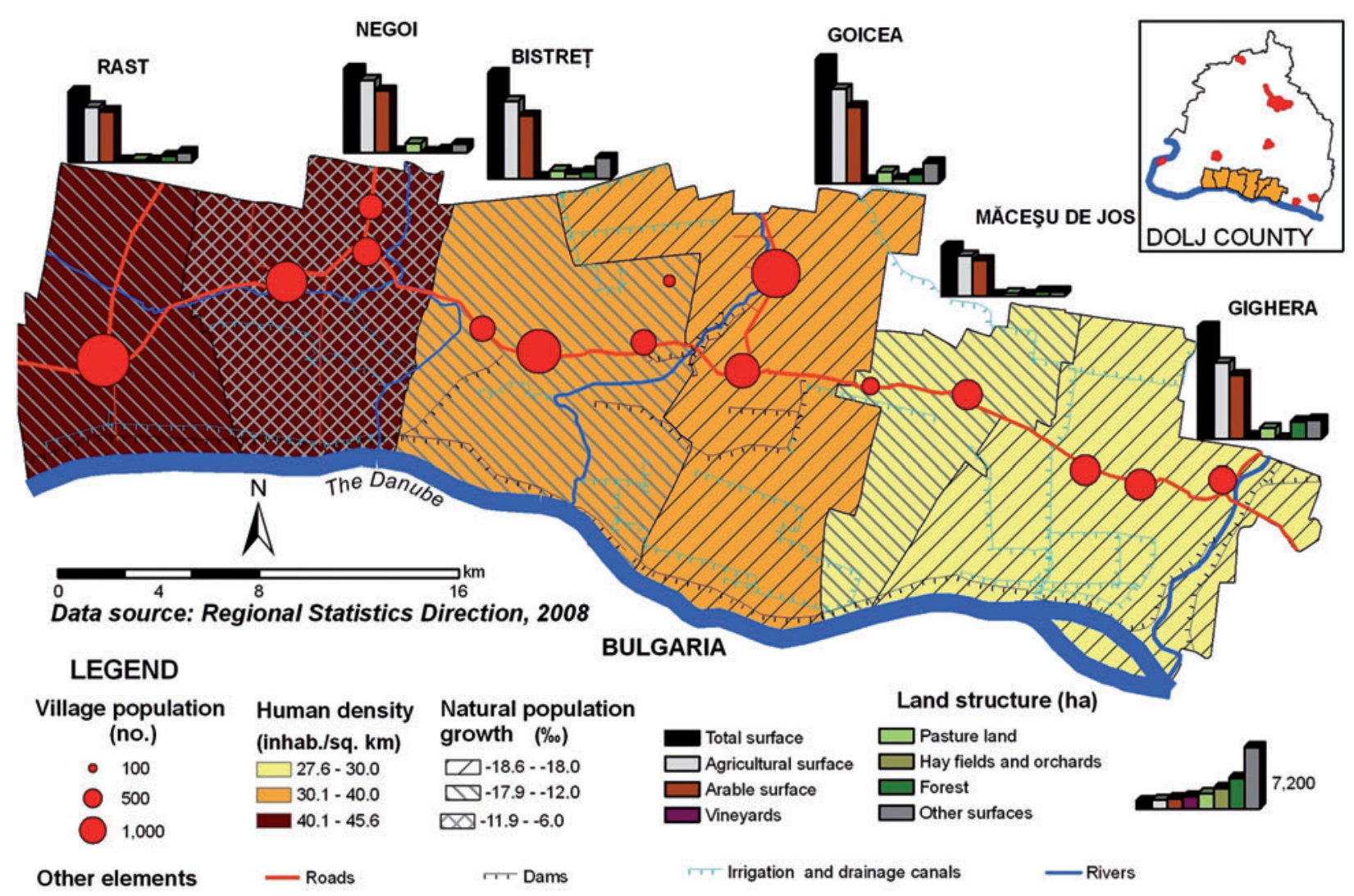

Fig. 3. The Rast - Gighera sector of the Danube Floodplain. Main administrative and demographic features

of the land use and land cover dynamics, as well as the connexion of these transformations with the occurrence of risk phenomena in the Danube Floodplain (Licurici 2010.). We adopted typical floodplain analysis, which involves three major steps: data collection and preparation, model development and execution, and floodplain mapping (Shamsi 2008). We created a GIS database comprising 25 thematic layers and tables related to the natural background, the infrastructure, and the social-demographical features.

Statistical analysis allowed for a better understanding of the aspects concerning social vulnerability to the natural and man-induced hazards and of the landscape transformation (Cutter et al. 2003).

Terrain observations have been conducted in order to reveal or to provide new details that were not observable on the maps (especially aspects concerning man-induced relief and the related hazards). The field trips enabled the more precise identification of the areas characterised by moisture excess or by soil salinisation, the direct observations on the occurrence mechanisms of floods in the area, as well as an evaluation of the psychological impact of these events on the population, by using the social inquiry (Tapsell et al. 2002).

\section{Results and discussions}

\section{Hydrological risk and improvement works}

The agricultural fields, very much extended during the past century, as well as the presence of settlements, were the main elements that led to the achievement of hydrological regilation works of great dimensions; their purpose was to reduce the hydrological risk related to the excess of moisture and especially to floods or, on the contrary, to the dry and drought phenomena. For this purpose, two visions took shape: the engineer Anghel Saligny proposed the damming of the Danube Floodplain by using nonsubmersible dams, while the great naturalist Grigore Antipa saw in the Danube Floodplain a region that was necessary for the regulation of the Danube flow at high water and an unmatched reservoir for fishing. Antipa proposed the Danube be dammed by 
Table 1. Main features of the Ghidici - Rast - Bistret - Nedeia - Jiu system of dams

\begin{tabular}{|c|c|c|c|c|c|c|c|}
\hline No. & System & $\begin{array}{c}\text { Surface } \\
\text { (ha) }\end{array}$ & Interval & $\begin{array}{c}\text { Long. dam* } \\
\text { (km) }\end{array}$ & $\begin{array}{c}\text { Part. dam** } \\
\text { (km) }\end{array}$ & $\begin{array}{c}\text { Drained sur- } \\
\text { faces (ha) }\end{array}$ & $\begin{array}{c}\text { Irrigation } \\
\text { system (ha) }\end{array}$ \\
\hline 1. & Ghidici-Rast-Bistreț & 9,031 & $1959-1962$ & 22.70 & 5.3 & 9,031 & 1,000 \\
\hline 2. & Bistreț-Nedeia-Jiu & 21,575 & $1967-1969$ & 39.13 & - & 21,575 & 268 \\
\hline
\end{tabular}

* longitudinal dam, ** partitioning dam

Source: Geografia Văii Dunării Româneşti, 1969.

using the submersible dams, with the purpose of serving alternatively, both agriculture and fishery. He also mentioned the fertilization of the agricultural land through periodical flooding (Antipa 1910).

Following the economic vision of the time, the idea of the nonsubmersible dams gained and the Danube Floodplain was divided into 70 natural units, among which three are situated within the area under study, starting with the kilometre 736 and up to the kilometre 693 (river kilometres on the Danube) and having a cumulative floodprone surface of about 30,000 ha.

After 1960, there were realized the most significant damming, irrigation and drainage works in the region, which led to the transformation of the area into a polder with predominantly agricultural function. There were constructed nonsub- mersible defence dams along the Danube, backwater dams on the Jiu and on the Desnățui rivers, partitioning dams (the total length surpassing 75 kilometres), a dense network of drainage and irrigation channels with reversible pump stations. The Ghidici - Rast - Bistret, - Nedeia - Jiu system of dams represents one of the most important defence lines at the Danube (Table 1), cumulating almost half of the total length at the Dolj County level. Within the dammed spaces, the organization of the defence is a requirement of the fact that they include large agricultural areas, power equipment, and populated centres.

Before the damming, the land use pattern of the floodplain was characterized by the prevalence of pastures and meadows (39.2\%), followed by ponds and marshes or reed-beds (34.2\%), by forests $(7.3 \%)$ but also by unproductive surfaces

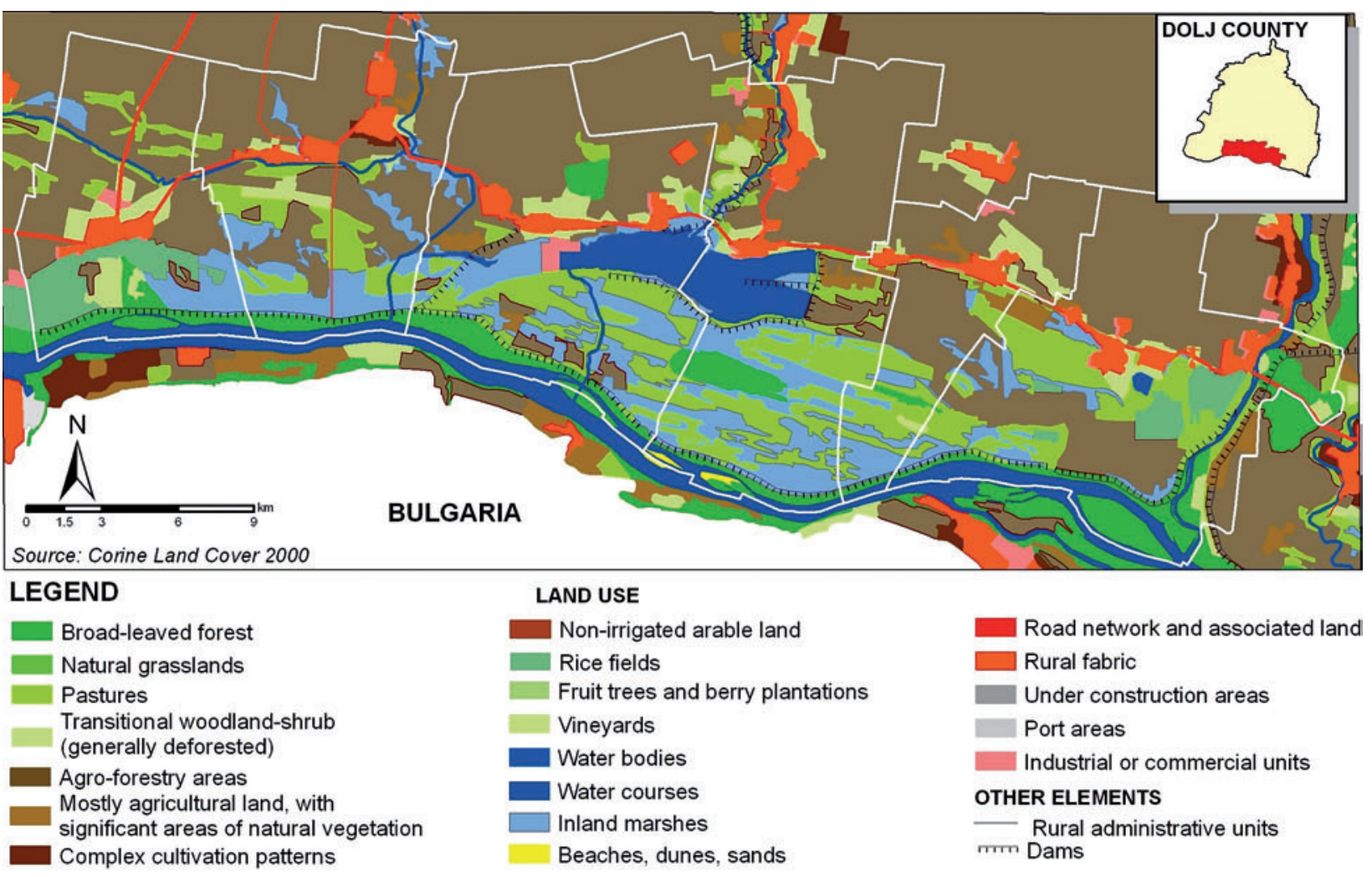

Fig. 4. The Rast - Gighera sector of the Danube Floodplain. Land use and land cover 
$(4.2 \%)$ (Tomescu 1998). Due to the hydrological works, the intensive agriculture within the area became possible. The part of the arable land increased significantly $(70.7 \%)$, while the ponds, marshes $(11.4 \%)$, pastures and meadows $(8.5 \%)$ and forests (5\%) suffered important losses (Licurici, 2010) (Fig. 4).

\section{Hazard inventory}

\section{Factors and categories}

There are two important triggering factors in the genesis of the hazards that are characteristic for the Rast - Ghidici floodplain. The climate represents a significant natural factor, generating periodical stress through extreme and persistent phenomena. The man-related elements are connected to the inappropriate human use of vulnerable ecosystems.

Our research identified two main categories of natural hazards within the study area. The first class refers to natural hazards triggered by drought phenomena and intensified by human intervention. Their main characteristics are the following:

- They are combined with other (geomorphologic, hydrological, pedological, or ecological) natural hazards.

- Prolonged drought conditions amplify the thermal effect, increase the potential evapotranspiration, while the moist deficit within soil becomes very high (sometimes over 300400 mm/year) (Mărinică 2006). The comparison of the previous studies on the 1961-2000 period (Vlădut 2004) with the data characteristic to the 2000-2008 interval (the Oltenia Regional Meteorological Centre, 2009) highlights a succession of deficit periods of different lengths, in consecutive years (six cases for two consecutive years, two cases for three consecutive years and only one instance of four consecutive cases). The maximum intensity of drought was reached in the summer of 1993 and it affected the entire southwestern part of Romania. The extension and the severity of the phenomenon determined the adoption of the Law 70/1993, regarding the covering of the expenses for setting up the agricultural cultures.
- The concentration of salts brought by upward water movement increased due to intense capillarity; in turn, this was determined by the evaporation processes that take place at the surface of the soil; physiological and phenological changes of the soil.

- Soils became saline, with halophile vegetal associations (Salicornia herbaceea).

The second class includes natural hazards triggered by excessive humidity and intensified by human intervention and refers especially to the following elements:

- The underground water reaches higher levels and generates excess of moisture, soil desalinisation, bog lands, lakes, gleyzation processes (Pleniceanu 1999); the data was collected from the hydro-geological network that includes 25 drills for the aquifer. The depth of the water table varies between 2 and 5 meters (Catane 2.20 meters/drill 3, Măceşul de Jos - 3.00 meters/drill 4, Zăval - 2.40 meters/drill 5, Rast 2.08 meters/drill 1, Negoi - 4.80 meters/drill 1, Bistrețul Nou - 4.34 meters/drill 1, Bistreț - 2.38 meters/drill 1).

- Salt dissolution, vertical transportation, which causes rising groundwater table, leads to piping and compaction of loess deposits.

- The development of a hydrophile vegetation, in the first stage, and of a halophile one subsequently, after the withdrawal of the water.

- Floods.

\section{Case study one: land degradation}

This type of hazard became a feature of the sector in the second part of the past century. The significant damming and deforestation, the agricultural use of soils with high degradation potential (Fig. 5) and the poor cultivation of agricultural land, coupled with extreme weather conditions are among the most important triggering factors.

Deflation and salinisation are two of the processes that intensify edaphic drought in the region. The blown sand layer, which is difficult to fix by vegetation in the absence of special measures, is exposed; the albedo increases and the evapotranspiration strongly intensifies; the fields and crops are covered with blown sand, while the water storage capacity of the soil and its capacity to ensure vegetation growth are significantly reduced 


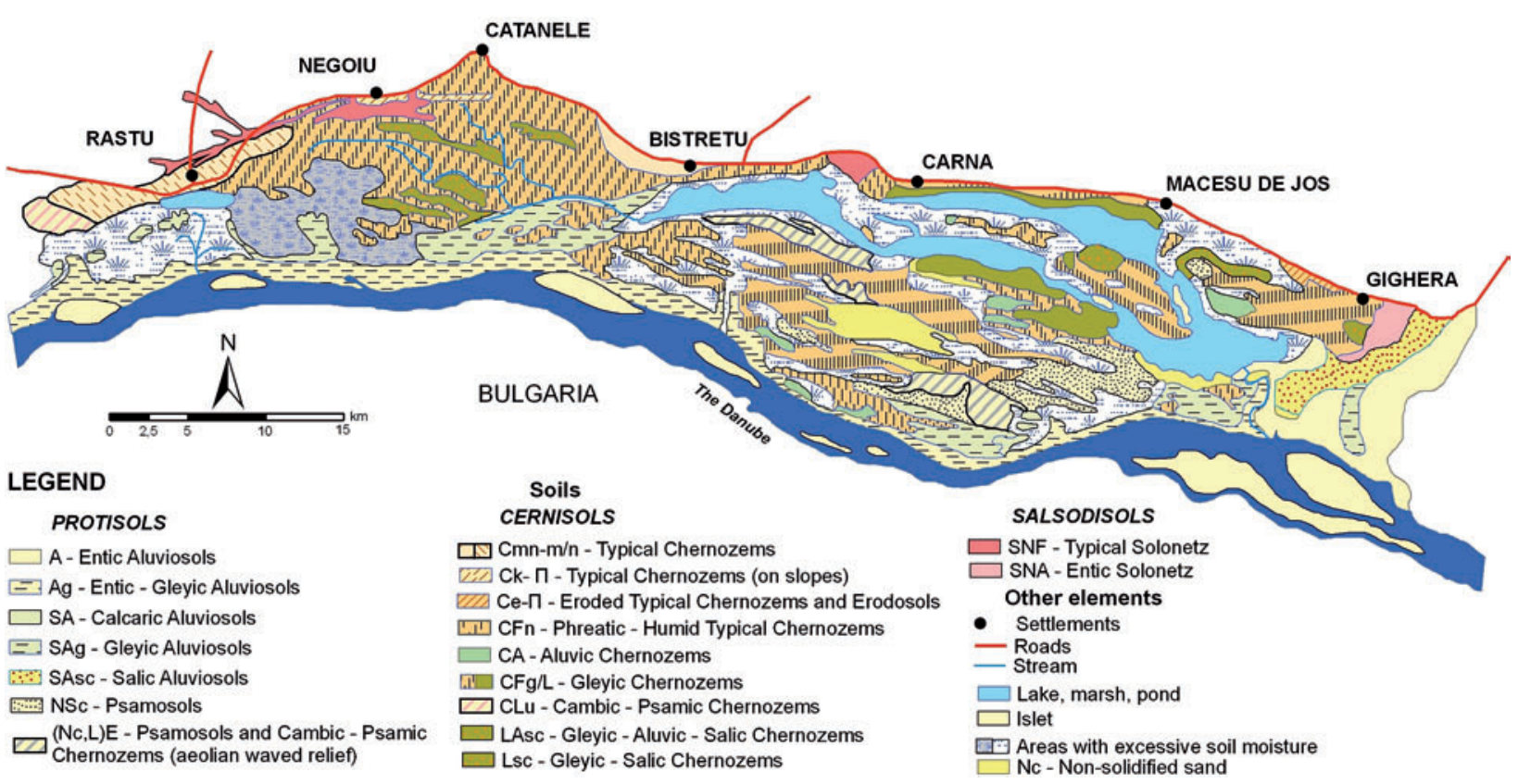

Fig. 5. The Rast - Gighera sector of the Danube Floodplain. Soils

through the removal of the uppermost horizons rich in organic matter.

The salinisation becomes manifest through the increase of the osmothic pressure of the soil, above that of cultivated plants, through the enhancement of surface flow, through the increase of albedo and the intensification of evaporation.

\section{Case study two: floods (very high flow, prolonged pressure on dams)}

Within the intervals 1234-1235 and 1267-1268, the first exceptional high floods were registered on the Danube, being generated during the cold season, through thawing. They were followed by the 1317, 1433 and 1490 floods, as well as by the more recent ones, in 1895 and 1897. These high floods show a return period of about 100 years, the maximum flow being reached in $1985(15,900$ $\left.\mathrm{m}^{3} \mathrm{~s}^{-1}\right)$ and in $1897\left(15,100 \mathrm{~m}^{3} \mathrm{~s}^{-1}\right)$. During the $20^{\text {th }}$ century, high floods occurred in 1940, 1942, 1970 and 1981, the registered flows showing values comprised 14,700 and 15,200 $\mathrm{m}^{3} \mathrm{~s}^{-1}$ (Diaconu 2007).

The highest flow $\left(15,800 \mathrm{~m}^{3} \mathrm{~s}^{-1}\right)$ registered over the entire measurement period in Romania (18402006) occurred in the spring of 2006 (April-May) and was due to the simultaneous occurrence of high floods on the Danube, the Tisa, the Sava, the Velika, the Morava and the Timiş Rivers. In the same period, the registered levels were about 60 centimetres higher than the levels reached at the highest floods that took place after the regulation of the Danube Floodplain (Fig. 6).

The propagation of moist air masses towards Eastern Europe added new water volumes to those already existent, which created the premises for surpassing the danger levels. To the hydrometeorological elements, there are to be added specific relief aspects, the Dolj sector of the Danube Floodplain being the first to extend exclusively in the southern part of a plain.

The water levels reached very high (historical) levels, leading to overflows (Fig. 7). Numerous households and extended agricultural fields were covered by water (Figs. 8, 9), an important number of persons were evacuated and an entire village needed to be moved and built again on safer locations (Tables 2, 3, 4).

After April 27 ${ }^{\text {th }} 2006$, the flow levels of the Danube constantly decreased and the evolution of breaches slowed down. Moreover, after May $2^{\text {nd }} 2006$, the flows and the levels reached the values corresponding to middle March (Figs. 10, 11). Yet, the complete withdrawal of the water was a long-term process, because huge water volumes had entered the dammed areas under specific relief conditions (Pleniceanu et al., 2006).

Four months after the flood, considerable surfaces covered with water (more than 7,600 ha) still existed in the Danube Floodplain (Fig. 12). 


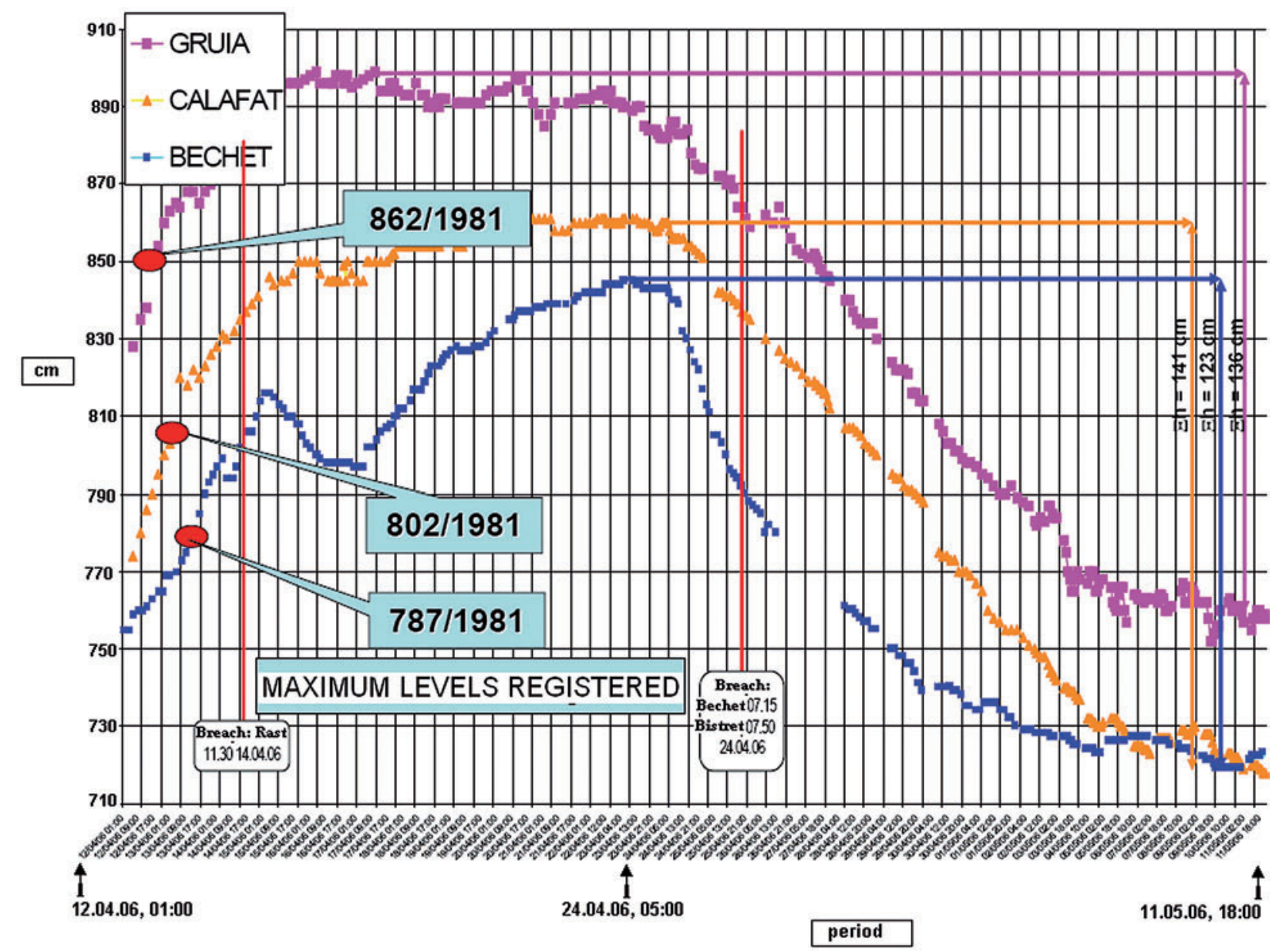

Fig. 6. The Danube River level variation during the April $12^{\text {th }}-$ May $12^{\text {th }} 2006$ period (Gruia - Bechet sector) Source: Romanian Ministry of Environment, 2006

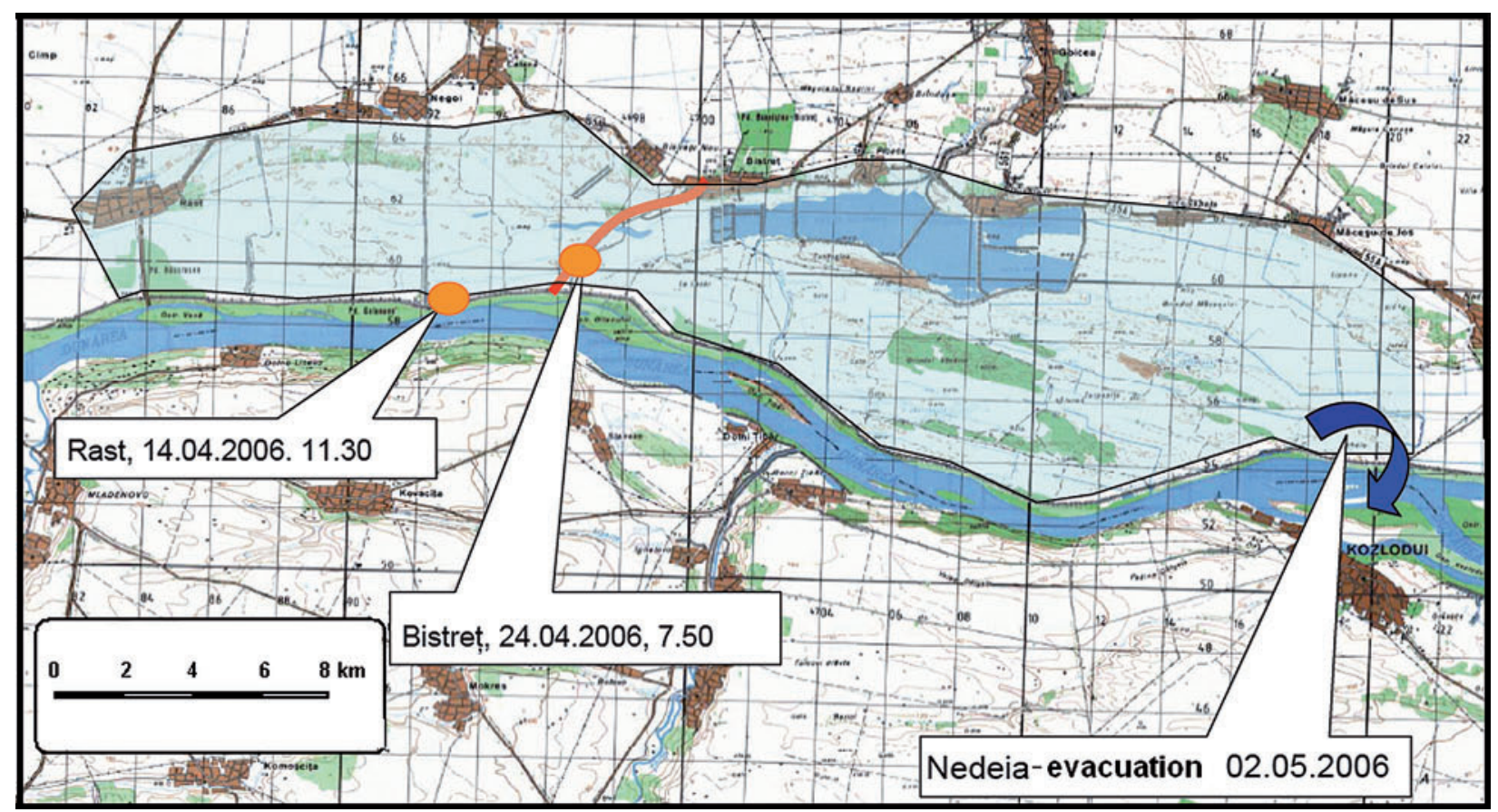

Fig. 7. The breaches at Rast, Bistret, Nedeia and the surface covered with water Source: Romanian Space Agency, 2006. 
Table 2. Main breaks and surfaces affected by water

\begin{tabular}{|c|l|c|c|c|}
\hline No. & \multicolumn{1}{|c|}{ Damaged dams } & Date/hour & Surface (ha) & Volume (mil. cubic meters) \\
\hline 1. & Rast - Bistreț & $14.04 .06 / 11.30$ & 12,000 & 480 \\
\hline 2. & Bistreț - Nedeia & $24.04 .06 / 07.50$ & 15,000 & 225 \\
\hline 3. & Nedeia & 02.05 .06 & \multicolumn{2}{|c|}{ Eviction breach } \\
\hline
\end{tabular}

Source: Romanian Ministry of Environment, 2006.

Table 3. Damage caused by the flooding of Ghidici - Rast - Bistret, dammed area

\begin{tabular}{|l|c|c|c|c|c|c|c|c|}
\hline Settlement & $\begin{array}{c}\text { Cultivated } \\
\text { arable land } \\
\text { (ha) }\end{array}$ & $\begin{array}{c}\text { Pastures } \\
\text { and } \\
\text { meadows } \\
\text { (ha) }\end{array}$ & $\begin{array}{c}\text { Flooded } \\
\text { households } \\
\text { (no.) }\end{array}$ & $\begin{array}{c}\text { Social- } \\
\text { economic } \\
\text { units } \\
\text { (no.) }\end{array}$ & $\begin{array}{c}\text { Bridges, } \\
\text { footbridges } \\
\text { (no.) }\end{array}$ & $\begin{array}{c}\text { Roads } \\
\text { (km) }\end{array}$ & $\begin{array}{c}\text { Damaged } \\
\text { houses } \\
\text { (no.) }\end{array}$ & $\begin{array}{c}\text { Destroyed } \\
\text { houses } \\
\text { (no.) }\end{array}$ \\
\hline Rast & 4,500 & 600 & 800 & 7 & - & - & - & 140 \\
\hline Negoi & 2,800 & - & 288 & 4 & - & 14.4 & 131 & 58 \\
\hline Catane & 740 & 300 & - & - & 16 & 0.5 & - & - \\
\hline TOTAL & 8,040 & 900 & 1,088 & 11 & 16 & 15.0 & 131 & 198 \\
\hline
\end{tabular}

Source: Dolj County Committee for Emergency Situations, 2006.

Table 4. Damage caused by the flooding of Bistret - Nedeia - Jiu dammed area

\begin{tabular}{|l|c|c|c|c|c|c|c|c|}
\hline Settlement & $\begin{array}{c}\text { Cultivated } \\
\text { arable } \\
\text { land (ha) }\end{array}$ & $\begin{array}{c}\text { Pastures } \\
\text { and } \\
\text { meadows } \\
\text { (ha) }\end{array}$ & $\begin{array}{c}\text { Flooded } \\
\text { house- } \\
\text { holds } \\
\text { (no.) }\end{array}$ & $\begin{array}{c}\text { Social- } \\
\text { economic } \\
\text { units } \\
\text { (no.) }\end{array}$ & $\begin{array}{c}\text { Bridges, } \\
\text { footbridges } \\
\text { (no.) }\end{array}$ & $\begin{array}{c}\text { Roads } \\
\text { (km) }\end{array}$ & $\begin{array}{c}\text { Damaged } \\
\text { houses } \\
\text { (no.) }\end{array}$ & $\begin{array}{c}\text { Destroyed } \\
\text { houses } \\
\text { (no.) }\end{array}$ \\
\hline Plosca & 2,485 & 1,115 & - & 19 & 25 & - & - & 180 \\
\hline Cârna & 2,600 & 500 & 550 & 11 & 2 & 2 & 320 & 230 \\
\hline Măceşude Jos & 3,285 & 599 & 312 & - & - & - & 201 & 34 \\
\hline TOTAL & 8,375 & 2,214 & 862 & 30 & 27 & 2 & 521 & 444 \\
\hline
\end{tabular}

Source: Dolj County Committee for Emergency Situations, 2006,

A special case was that of the settlement of Rast: proceeding from the decision taken by the National State Administration, it has been approved to displace the locality seven kilometres northwards of its old site (Boengiu et al. 2008) (Fig. 13).

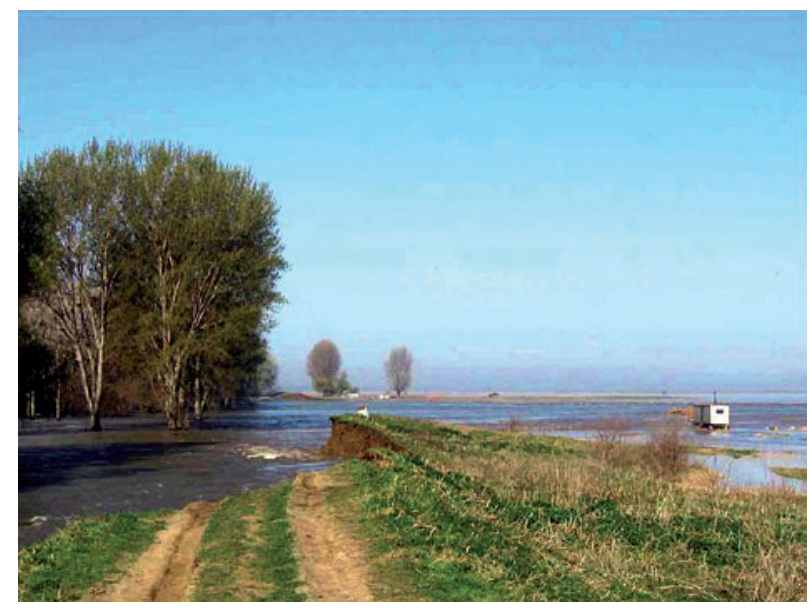

Fig. 8. The breach appeared in the Danube dam, south Catane, 2006
After the exceptional hydrometeorological phenomena that affected the southern part of Romania in the spring of 2006, the National Committee for Emergency Situations decided to set up a work group in order to analyse the options for the reconstruction of flood-defence systems.

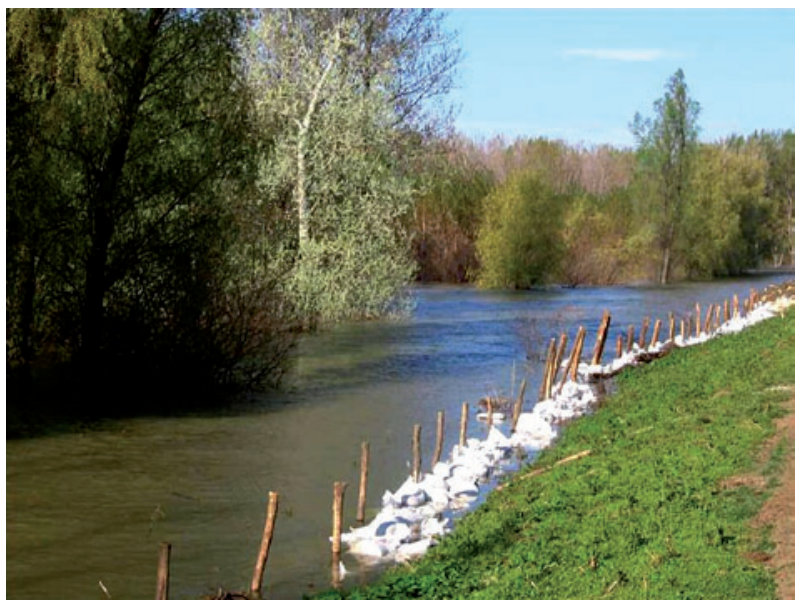

Fig. 9. Reinforcement of the Danube dam - the Rast - Bistreț area, 2006 


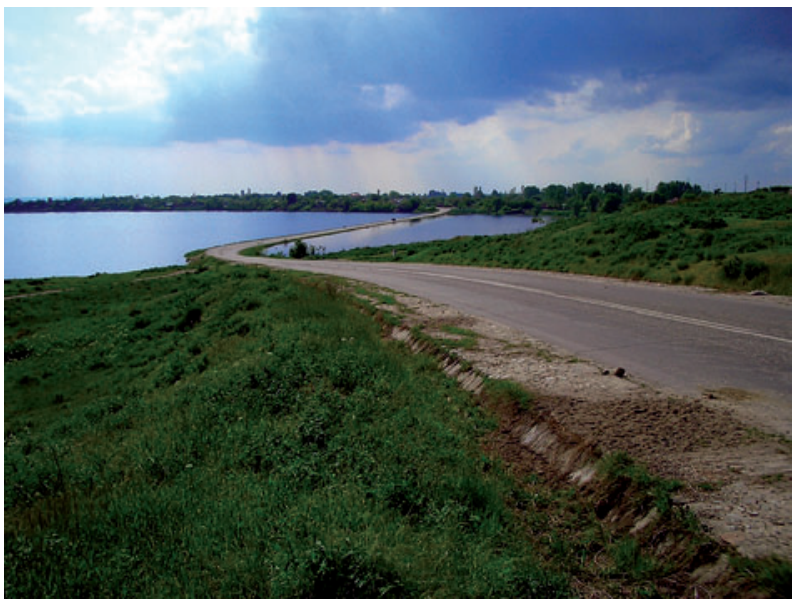

Fig. 10. National road 55 A (between Zăval and Gighera settlements), 2006

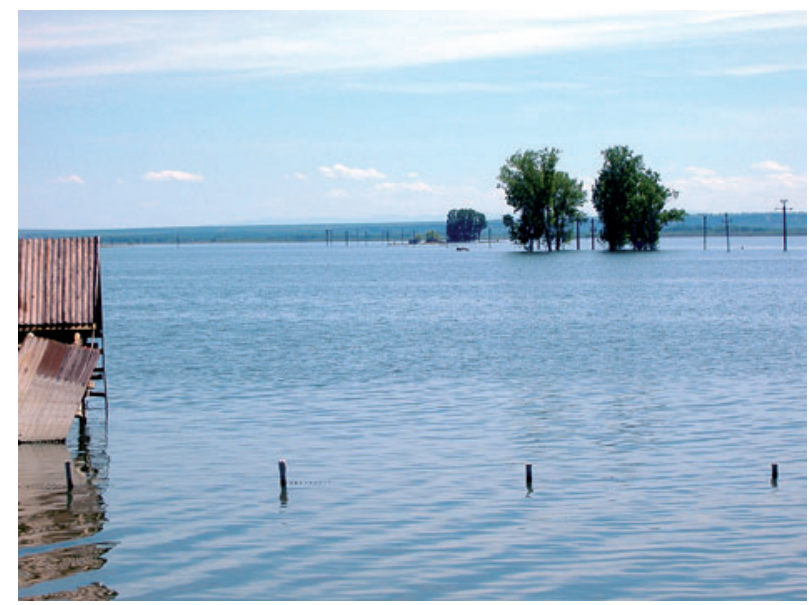

Fig. 12. Rast - Bistreț dammed area, four months after the 2006 flood

The alternatives concerning the Danube and its alluvial plain must be based on the National Strategy for the Management of the Flood Risk, which, in turn, took into consideration the European principles for water management (Klijn et al. 2008). These principles are included in the European Directive on Flood Risk Management, which refers to the protection of the population and of its goods through the creation of certain structural defence works: lakes, polders, dams, high water derivations, as well as to the restoration of certain wet areas with the aim of conservation and developing the biodiversity and attenuating the maximum flows of the freshet waves.

There are certain alternatives for the reconstruction of the Danube Floodplain:

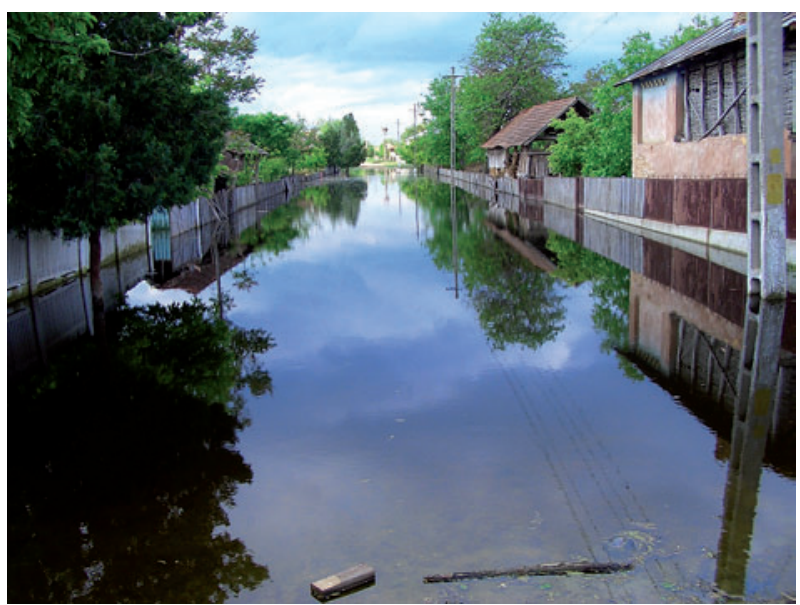

Fig. 11. Cârna village during the 2006 flood

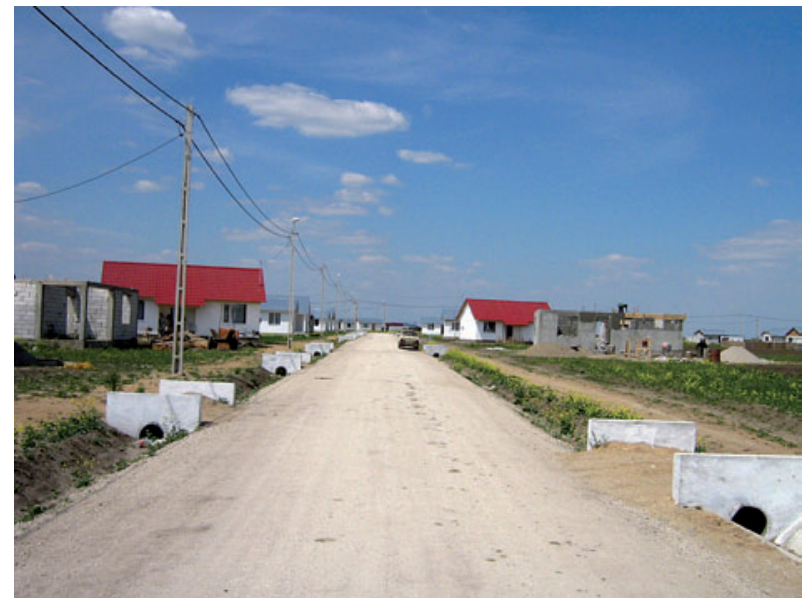

Fig. 13. The new settlement of Rast, built after the 2006 flood

1. to rebuild all dykes and dams that were damaged by the extreme flood and to bring them at least at the initial functioning levels;

2. to restore the floodplain into natural conditions through the construction of wetlands along the Danube;

3. to rebuilt the damaged dams, combining this action with the creation of polders in order to allow controlled flooding in emergency situations and for wetlands.

\section{Conclusions}

The degradation and the gradual abandonment of the irrigation system, after 1989, the deficient drainage of certain areas with excess of moisture and the poor maintenance of the dam 
system amplifies the hydrometeorological phenomena of risk that are characteristic of the floodplain.

The fight against the natural and man-induced risk phenomena implies the reduction of vulnerability (of population, infrastructure, crops etc.). This can be realised through the reconstruction and the appropriate maintenance of the existent infrastructure and through the diversification of the economic activities (for example, the partial replacement of the extensive agricultural activities with those related to rural tourism) (Licurici et al. 2008).

The hazard analysis and especially the study of the catastrophic 2006 floods registered on the Danube had not only an informative character, but they were mainly conducted with the purpose of understanding the occurrence mechanism, the effects and the systemic intromissions of these natural phenomena, as well as for the improvement of the response to the dangerous phenomena.

\section{Acknowledgements}

The subject of our research concerns significant landscape changes and certain dramatic human events. The authors express their sincere compassion to the families who were affected by the 2006 events, hoping that a better understanding of the circumstances that led to them will help improve warning and consciousness.

The authors bring their special thanks to the researcher Lucian Badea (the Geography Institute of the Romanian Academy) for his numerous early studies that were at the base of the research on the Danube Floodplain.

Our research would not have been possible without the support of certain specialised institution, such as the Jiu River Water Directorate, the Oltenia Emergency Situations Inspectorate Dolj county (the collaboration initiated between this institution and the University of Craiova represented the starting point in the research of the dangerous natural phenomena in the Danube Floodplain), the Oltenia Regional Meteorological Centre, the Dolj Office for Cadastre and Real Estate Advertising, the Dolj Regional Directorate of Statistics.
We are also grateful to our reviewers for their helpful comments on the first draft.

\section{References}

ANTIPA Gr., 1910. Regiunea inundabilă a Dunării, starea ei actuală şi mijloacele de a o pune în valoare (The flood-prone Danubian region, its current status and means of valorising it), Carol Göhl Institute of Graphic Arts, Bucharest.

BĂLTEANU D. \& ŞERBAN M., 2005. Modificări globale ale mediului. $O$ evaluare interdisciplinară a incertitudinilor (Global environmental changes. An interdisciplinary assessment of uncertainties), Coresi Publishing House, Bucharest.

Boengiu S., Ionuş O., Boengiu A. \& Licurici M., 2008. Poluarea apei freatice şi potențialitățile patogene generate de inundatiile din 2006 în comuna Rast (Phreatic layer pollution and pathogenic potentialities induced by the 2006 flood in Rast settlement), Arhivele Olteniei, 22: 225-233.

BOGDAN O. \& MARINICĂ I., 2007. Hazarde meteo-climatice din zona temperată. Geneză şi vulnerabilitate cu aplicații la România (Meteorological and climatic hazards in the temperate zone. Genesis and vulnerability with applications for Romania), Lucian Blaga Publishing House, Sibiu.

Cutter S., Boruff B.J. \& Shirley W. Lynn, 2003. Social Vulnerability to Environmental Hazards, Social Science Quarterly, 84(2): 242-261.

Diaconu D.C., 2007. Inundațiile din anul 2006 produse în Lunca Dunării (The 2006 floods occurred in the Danube Floodplain), Comunicări de Geografie, XI: 271-276.

Dumitrașcu M., 2006. Modificări ale peisajului în Câmpia Olteniei (Landscape changes within the Oltenian Plain), Publishing House of the Romanian Academy, Bucharest.

Glade T., Malamud B., Roulston M. \& Ferraris L. (eds.), 2004. Multidisciplinary approaches in natural hazards - Special Volume in Natural Hazard and Earth System Sciences $4(2)$.

Klijn F., Samuels P. \& Van Os Ad, 2008. Towards flood risk management in the EU: State of affairs with examples from various European countries, International Journal of River Basin Management, 6(4): 307-321.

LicURICI M., 2010. Assessment of the human impact on the landscape of the Danube Floodplain, in Drobeta-Turnu Severin - Bechet sector, Annales of the University of Craiova, Biology, Horticulture, Food produce processing technology, Environmental engineering Series, XV (XLXI): 323-330.

Licurici M., Curcan Gh. \& Popescu L., 2008. Potențialul turistic al Luncii Dunării - Sectorul Oltean (The tourist potential of the Danube Floodplain on the Oltenian sector), Papers of the Annual Congress of the Romanian Society of Geography, Presa Universitară Clujeană Publishing House, Cluj-Napoca: 65-76.

MARINICĂ I., 2006. Fenomene climatice de risc în Oltenia (Climatic phenomena of risk in Oltenia), Autograf MJM Publishing House, Craiova.

Pleniceanu V., 1999. Apele din Campia Olteniei (The water bodies within the Oltenian Plain), Universitaria Publishing House, Craiova.

Pleniceanu V., Tomescu V., Golea C., Marinescu I., Iordache C., Curcan Gh., Vlăduț A., Popescu L., Boengiu S., MariNESCU E., IONUS O. \& LICURICI M., 2006. The rehabilitation 
of the Danube Floodplain on Rast - Corabia sector, Annals of the University of Craiova, Geography Series, IX: 5-68.

Savin C., 2003. Râurile din Oltenia. Fenomene hidrografice de risc exceptional (The Oltenian rivers. Hydrographical phenomena of exceptional risk), Universitaria Publishing House, Craiova.

Shamsi Uzair M.U., 2008. GIS Applications in Floodplain Management, available at http://gis.esri.com/library/userconf/proc02/pap0490/p0490.htm.

Tapsell S.M., Penning-Rowsell E.C., Tunstall S.M. \& Wilson T.L., 2002. Vulnerability to flooding: health and social dimensions, Philosophical Transactions of the Royal Society, Mathematical, Physical and Engineering Sciences, DOI: 10.1098/rsta.2002.1013, London, pp. 1511-1525.

Tomescu V., 1998. Lunca Dunării - sectorul oltean (The Danube Floodplain on the Oltenian sector), Sitech Publishing House, Craiova.

VLĂDUȚ A., 2004. Precipitation deficit within Oltenia Plain between 1961 and 2000, Geographical Phorum. Geographical studies and environmental research, 3: 99-104.

VLĂDUȚ A., 2007. Air temperature regime within the Danube alluvial plain (Drobeta Turnu-Severin - the Olt sector), Geographical Phorum. Geographical studies and environmental research, 6: 102-110.
*** 1969. Geografia Văii Dunării Româneşti (Geography of the Romanian Danube Valley), Publishing House of the Romanian Academy, Bucharest.

*** 2001. Law No. 575/22.10.2001 concerning the National Territory Arrangement Plan - Section V - Natural risk areas (Appeared in the Official Gazette No. 726/14.11.2001).

*** 2004. Flood Action Programme. Action Programme for Sustainable Flood Protection in the Danube River Basin (International Commission for the Protection of the Danube River (ICPDR) along with the countries in the Danube River Basin).

*** 2006. Report on the defence against floods, dangerous meteorological phenomena, accidents at the hydrotechnical constructions and accidental pollution in Dolj County, April-May 2006 - Issued by the Dolj County Committee for Emergency Situations.

*** 2007. National Strategy for the Flood Risk Management. Prevention, Protection and Diminution of Flood Effects (Romanian Ministry of Environment).

*** 2007. DIRECTIVE 2007/60/CE on Flood Risk Assessment and Management.

*** 2008. http://www.eea.europa.eu - Corine Land Cover 2000 Database.

*** 2008. http://web.rosa.ro - Romanian Space Agency (Floods in Romania, April 2006. Preliminary data Processed by ROSA, CRUTA, ANM, DLR).

*** 2008. http://www.mmediu.ro - Romanian Ministry of Environment. 